\title{
Emigrants and wine
}

\author{
Shaun R. McCann ${ }^{1}$
}

Received: 19 June 2019 / Accepted: 19 June 2019 / Published online: 29 July 2019

(c) Springer Nature Limited 2019

'I wanted real adventure to happen to myself. But real adventures, I reflected, do not happen to people who remain at home: they must be sought abroad'.

An Encounter. From 'Dubliners'. By James Joyce. Irish writer, poet and literary critic (1882-1941).

Emigration/immigration are two sides of the same coin. They both provoke emotional responses, which are often fiercely contested. Western history is full of examples of people who emigrated and brought their culture with them. For example, the Greeks went to Italy, the Romans went to France, Italy, Spain, England and North Africa, the Persians went to Greece and Alexander the Great went as far as the Indus valley. In more recent times the Germans, Irish and Italians went to the United States in large numbers. They were not always welcomed as they were often poor, disease ridden, ill—educated and did not speak English. However, all three emigrant populations have made a significant contribution to life in the United States.

More recently emigration occurred in the 1930s from Germany and Italy because of the policies of Hitler and Mussolini. This proved to be totally counter-productive as it resulted in many intellectuals, Jews and others, emigrating from Germany (e.g. Albert Einstein/Walter Gropius) and Italy (Enrico Fermi) to the United States, UK, South America and South Africa to which they made many contributions. Opinions vary about the advantages immigration confers to a country/continent but many are of the opinion that it is beneficial. Except for the Native Americans, all current USA citizens are descended from immigrants.

Shaun R. McCann

shaunrmccann@gmail.com

1 University of Dublin Trinity College, Haematology Emeritus, Dublin, Ireland
Has emigration anything to do with wine? Of course, it has. The origin of vitis vinifera, a vine from which most wines in the world are made, is unclear but is probably somewhere around Iran, Iraq and Turkey or Georgia, Armenia or perhaps China. Vitis vinifera was spread by Phoenicians, Greeks, and Egyptians. The Greeks introduced vitis vinifera to France in $600 \mathrm{BC}$ and 600 years later it is thought the Romans introduced it to England [1]. While this is well known what many people do not know is that numerous famous Châteaux in Bordeaux were initiated by Irish men and women and thus emigration from Ireland to France had a profound influence on the French wine industry.

The 'great famine' in the 19th century is well known to most people but the influence of the Irish émigrés on French wine production is less well known. In his book 'A kingdom of wine' [2], Ted Murphy introduces the term 'Wine Geese', a pun on the term 'Wild Geese'. This term generally refers to Irishmen who fought as mercenaries in Continental armies in the 16th-18th centuries. The 'Flight of the Wild Geese' was the departure of an Irish Jacobite army under the command of Patrick Sarsfield from Ireland to France, in 1691 , following the end of the Williamite War. The 'Wine Geese' refers to those families who created wine making estates in various parts of France in the aftermath of this migration. Many Irish surnames survive in Bordeaux such as Lynch, Dillon, Kirwan, Barton and his friend Bernard Phelan (Figs. 1 and 2). Barton had the distinction of being imprisoned in the Bastille and was also 'the first man out' after the storming. Originally from Fermanagh, his descendants still live in St Julien in the beautiful Château Langoa-Barton. So, the next time you are drinking wine from any of these Châteaux think of the origin of the name on the label.

More famous in the context of making spirits, is Hennessy, a name that most people will know even if they do not drink Cognac. Richard Hennessy was born in Cork and served as an officer in the regiment of Arthur Dillon, a Jacobite soldier from Roscommon. He became colonel of the Dillon Regiment in 1688 and was made 'Comte Dillon' 


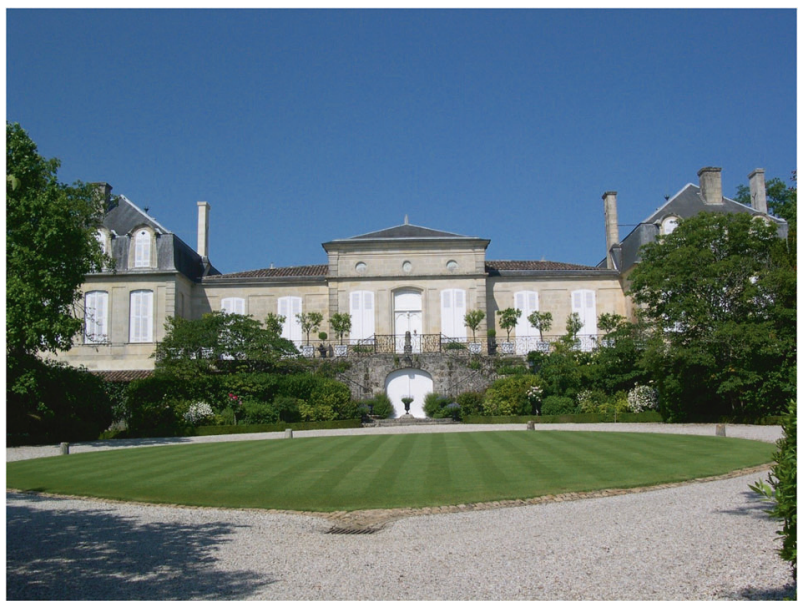

Fig. 1 Château Langoa-Barton. Photograph by S McCann

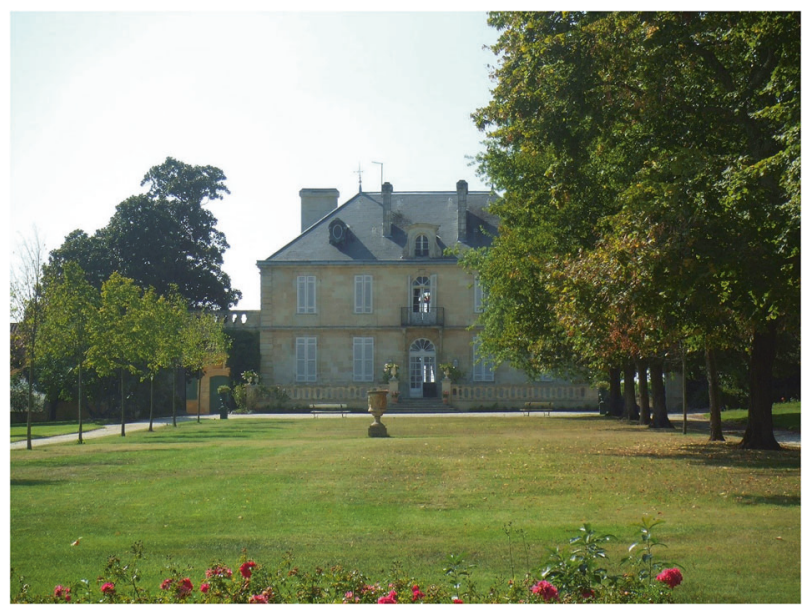

Fig. 2 Château Kirwan. Photograph S McCann by King Louis XIV. Hennessy eventually settled in Cognac, just north of the Bordeaux region, where he became a very successful exporter of cognac to customers including the Tsar of Russia [3].

Of course, many émigrés were responsible for influencing wine making. The Spanish introduced vitis vinifera to South America and California, the Dutch to South Africa and the British to Australia and New Zealand. If you are a wine drinker perhaps you will have a kinder view of emigrants...where would you be without them?

Shaun R McCann.

\section{Compliance with ethical standards}

Conflict of interest The authors declare that they have no conflict of interest.

Publisher's note: Springer Nature remains neutral with regard to jurisdictional claims in published maps and institutional affiliations.

\section{References}

1. Ted Murphy. A. Kingdom of wine. Cork, Ireland: Onstream Publications ltd; 2005. ISBN 1879685726.

2. Ibid. Chapter 3.

3. McCann Shaun. An immodest proposal-wine and health. 2013. Cork, Ireland: MPI Media ltd. ISBN 9781782802075. 